\title{
家族性原発性神経アミロイドージスの一家系
}

\author{
国立相模原病院内科 \\ 山崎昭吉沢攻島野媇八郎 \\ 東京大学睬研神経内科 \\ 別府宏图吉田光男塚越広
}

\section{FAMILIAL PRIMARY AMYLOIDOSIS}

Sagamihara National Hospital (Internal Medicine)

Akira Yamazaki, Osamu Yoshizawa and Kihachiro Shimano

Department of Neurology, Institute of Brain Research, University of Tokyo

Hirokuni Beppu, Mitsuo Yoshida and Hiroshi Tukagoshi

\begin{abstract}
概要 Amyloidosisの歴史はRokitansky(1842)が諸臟器に異常物質の沈着を見出し，Virchow（1853）

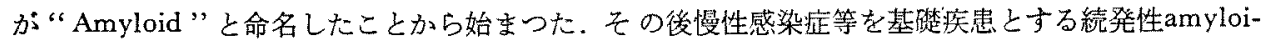

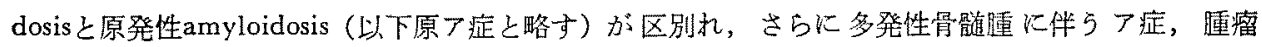
形成性のア症, 家族性了症も見出され，フミロイトの沈着様式, 部位等之関連して, その分類は多岐 であり，その臨床症状も著しく多様で確診が困難であつた。しかし組織生検が広く行なわれ生前に診 断される例も多くなつた，わが国に执いてはつ症は非常に少ないといかれていたが，近年著しい增加 を示している゙。ことに原了症は戦前僅が太田の報告 ${ }^{21} か ゙ 1$ 例あるだけだが，以後73例が報告され ている。しかし家族性原つ症の報告はまた少なく，中尾ら あるに過ぎない，われわれは最近本邦て第 3 例目々思われる家族坐原了症を経験したので，これを報 告するとともに文献的考察を行なつた.
\end{abstract}

\section{症 例}

症例は表 1 に示すごとく一家系 3 世代13人中 5 人に発病を見た例で，直接観察しえたのは兄（III -1)，弟 (II-2)の 2 例である。冊 $(\mathbb{I}-5)$, 叔 父 $(\mathbb{I}-6)$, 祖父 $(I-3)$ の 3 例はすでに死亡 して和り，扣名に兄弟の父親 (II-1) から病歴 を聴取した。叔母（II-7）に面会することは拒 否されたが，健康であつたという。

症例 1 (III-1). 39才, 男.

[昭和 43 年 3 月 9 日 第192回関柬地方会推壂]
主訴：知覚障害，筋力低下，便秘，眩量，羁 視，全身僚急。

既往歴：特になし。

現病歴： 昭和29年 (25才)ごろから便秘㑯向 となり，32年ごろから足のほてり，疲れを感し， ついで足にしびれを感じ，34年ごるから性欲減退 に気づき，36年ごろから立らくらみ，歩行障害， 便通不正が起こつた. 37年某大学病院で瘦病は否 定され，神経炎といわれた。

38年ごろから下肢の温覚が鈍麻し，熱傷を扣う 
表 1。家族性原発性アミロイドージスの一家采

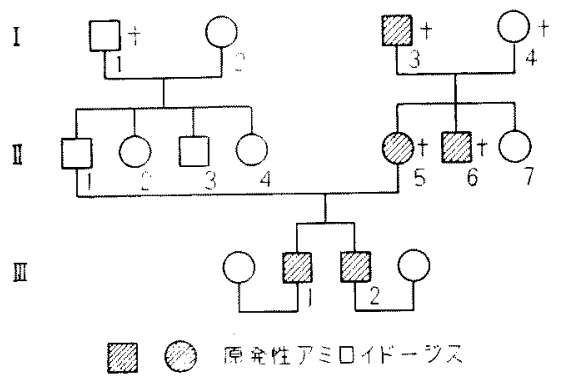

ようになり，下肢の発汗減少に気づき，時に排尿 困難をみた。39年 5 月ごろ，食欲不振，全身倦 急, 軽い黄疸, 霧視, 起立時に脳貧血様となり, 低血生を指摘され，昭和39年10月14日国立相模原 病院内科に入院した。

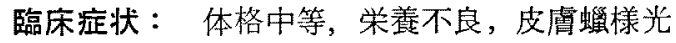
沢, 両下肢に熱傷㾝痕多数西り。顔貌浮腫状.
涙, 唾液，鼻汁の分泌低下あり，乾燥性角結膜 炎，鼻炎がある．巨大舌があるが，器下，言語の 障害，嗄声はない，胸部に著変なく，肝のみ僅か に触知す。入院時の黄㾝はその後間むなく消失 寸．その後口渴，鼻閉，便秘と下蜊の交代性発 現，立ちくらみがあり，時に発熱，不整脈，高血 圧および低血圧, 霧視, 排尿困難, 下肢の神経病 様疼痛があつた。

神経学的所見：瞳孔は右散大，左ほぶ正常. 対光, 輻軑反射は消失もしくは減弱. 歩行は踵歩 き，筫萎縮は四肢一ことに下肢に強い一一に中 等度以上，遠位部に著しい，筋力低下も四肢遠位 部で中等度（以上）である，知覚異常は四肢遠位 部で著明（図1），触覚，振動党に比へて，痛覚， 温度覚が強く浸され, 知覚解離がみられた。位置 覚は足趾で消失，諸反射は減弱ない乙消失，病的

图 1。知賞麻瘁の状㫛 $(\mathbb{I I}-1 ， \mathbb{I I}-2)$
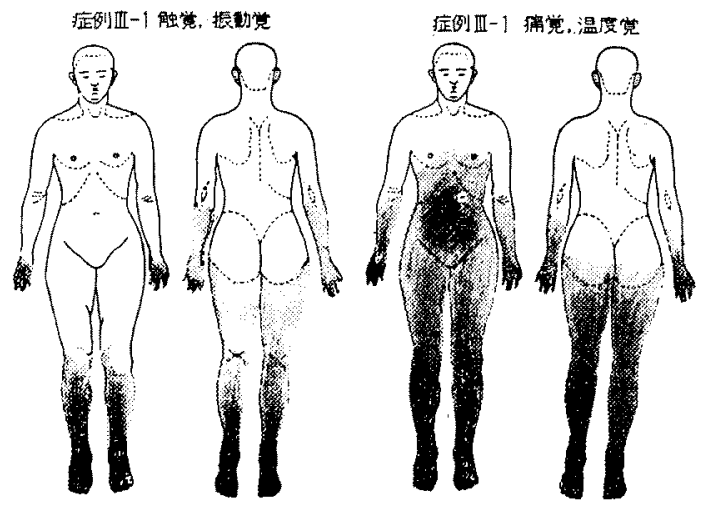

症㓢近-2
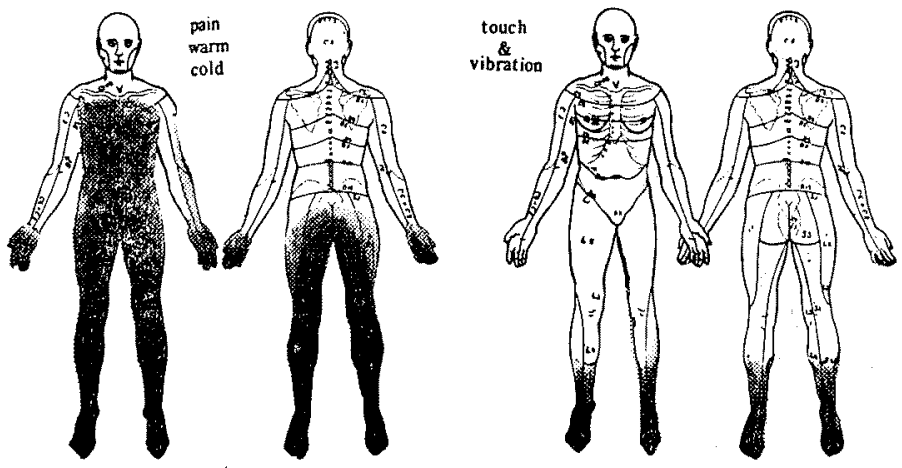
反射はない，発汗異常を温痛覚の障害域に一致し てみた。

臨床検查成績：中等度の貧血, 軽度の血沈促 進, 血清梅毒反応陰性. 肝機能はGOT, G P T, 血清ビリルビンが入院時高く，その後黄疸の消螁 こともに正常值になつた，C R P，RAは経過中 一時陽性となり，腎機能検査で軽度障害を認め， 心電図で期外収縌，㪕度の房室ブロックを゙みた。 起立試験では，血圧は卧位 150～104，立位70～ 46，顔面荅白となり不快感を訴えた。䯣液は蛋白 増加のほか異常なく，筋電図は四肢でhigh spike またはpolyphasic high V.を認めた。CPKの増 加をみとめ，ピロカルピン試験 $(+)$, シルマーテ スト(一)，添腺分泌減少を認めた。コンゴレッド 試験は30.5, 皮内に注射されるコンゴレットは数 カ月も認められている。脚腹神経の生検を行な い,愿線維のなかにコンゴレッド染色で赤沈す るアミロイドの沈着を認めた。

症例 2（II-2）。33才, 男.

主訴: 失神発作, 知覚障害, 下痢, 便秘, 性 欲減提, 能萎縮.

既往歴：22才で左康管結石剔出術。

現病歴：昭和 32 年 (22才) ごろから便秘傾向 となり，昭和36〜37年ごろから性欲減退に気付 $<$.

昭和39年ごろから筋萎縮，筋力低下，発汗異 常，手足が冷えやすいなどの症状が出現. 同年 8 月には立ちくらみ様の軽い失神発作があつたが， すぐに意識を回復した。このころから，便秘と下 㾥が交替にみられるようになつた。

昭和39年から40年にかけては，一時残尿感と艮 失禁があつたが自然に消失した。昭和 40 年 1 月初 めて某医に知覚障害があることを指摘されたが， この時既に現在とほら゙同様な障害の分布が完成し ていた．以後しばしば自分では知らずに熱傷を負 万. 同年 3 月某大学病院で筋生検をうけたが, amyloidの沈着は認められなかつた。この入院中 起立性低血圧症を初めて指摘され，失神発作が頻 発するよらになる。このころから左眼が时々ぼや けることに気づく、昭和41年ごろから源，哽液の 分泌低下，番閉定訴光，失神発作はさらに頻回亡 なり，多い时は日に $3 〜 4$ 回もあつた。同年 8 月 東大神経内科に入院した，入院中時々不整脈ある いは著しい徐脈があつた。 2 力月で軽快退院した が，昭和 42 年再び失神発作頻発，6月に第 2 回目 の入院をした。

入院時現症（第 1 回および第 2 回の入院で汪と んど変りない）：体格中等，意識清明，皮膚は 南下肢に熱傷㗪痕が多数あるが，難治性潰瘍はな い，顔貌浮腫状で，下肢にも軽度の浮腫がある。 血圧は卧位で $140 ／ 110$ ，立位で70／40，脈拍は 平常は75/分，整，時に著明な不整脈，徐脈を見 る、源，唾液の分泌低下，しばしぱ鼻閉を培古 た。巨大舌があるが，與葆下，言語に異常なく，嗄 声もなかつた。左眼に硝子体混浊を認める活か, 眼底等に異常所見はない，心界正常で，心尖部に 轻度の収縮期雑音をさく、腹部異常なし、神経学 的所見では，瞳孔右正円，左やや楕円，軽度散大 しているが大きさはほら゙等しい，対光反射消失， 輻輳反射は存する。四肢には中等度の遠位部に強 い筋萎樎があり，軽度の筋力低下がある，筋緊 張, 協同運動は正常. 図1に示すよらな知覚障害 がありことに下肢遠位部に著明である．触覚， 振動覚は全く正常であつた。アキレス琏反射はな いが，他の腱反射は正常ないし軽度元進，病的反 射はない，注ら゙温痛覚の障害域に一致して落明な 発汗低下があつた。

臨床検査成績： 尿蛋白（十）のほか原，屎に 特記すべきことなし，血色素 $76 \%$ ，赤皿球 384 万, 白血球 6,500. 血液像巽常なし。血沈 1 時間 值16, 血液で尿酸 $9.4 \mathrm{mg} / \mathrm{dl}$, 総蛋白 $5 . \mathrm{cmg} / \mathrm{dl}$, alb $53 \%, \alpha_{1} 4.3 \%, \alpha_{2} 9.4 \%, \beta 12.3 \%, \gamma 21 \%$. 
腎機能検查で， Fishberg試験最高1016， P S P $20 \%$ (15分), $55 \%$ (2 時間), R P F 473, G F R74.5，F F 0.158，心電図は低電位の傾向があ り, Q T 延長, $\mathrm{V}_{5}, \mathrm{~V}_{6}$ で $\mathrm{T}$ の平坦化が目立つ. 起 立試験を行ならと，血圧は $142 / 102$ から直ちに $76 / 38$ と低下，不快感を訴光，顔面蒼白となり 失神する。心電図では，著しい血圧下降にもかか わらずR R間隔はほとんど変らない。しかし間も なく不快感に引き続いて，突然にsinus arrestない しはSA blockを来たして心拍は停止する，意識 は混浊し，直ちに臥位に戻すと再び心拍動を開始 するが，著しく不整な徐脈で，下降した血圧は容 易に回復しない，心電図は極端な洞徐脈と房室結 節からの補充収縮が混じて見られる。30分から 1 時間ほどで平常に復する。髄液は䨞白 $54 \mathrm{mg} / \mathrm{dl} て ゙$, 他は正常である。筋電図は全体にcomplex NMV を認め,遠位筋でnormal NMVの減少を認めた。 たヒラメ筇, 前怪骨筋等でhigh amplitude NMV が見られた。アドレナリン試験陽性，アトロピン 試験陰性メメコリール試験 P型，シルーー試験は 0 . 腓腹神経生祫でamyloidの沈着と髄鞘・軸索 の破壊が認められ，ことに小経線維の脱落は著し かつた(写真 1 )。腎, 直腸の生検でもamyloid沈 着を認めるが，皮虞，筋，骨髄には認めない。

症例 $3(\mathrm{I}-3)$. 59才, 男.

患者の冊方の祖父. 若いころから歩行障害があ り, 笳萎縮, 下痢, 便秘, 知覚障害を示してい た. 59才で死亡したが晚年は全く歩行不能. 死因 等詳細については不明.

症例 4 (III-5). 39才，女.

患者の册.34才ころから倦意, 瘦せ，食欲低 下，下㾥・便秘を繰返す，次第に歩行困難とな り, 知覚鈍麻，足趾は難治性潰瘍のため著しく変 形，主治医からは癩と診断され，39才で病気を苦 に自殺.

症例 5（II-6). 34才，男.

患者の冊方の叔父. 29才ごろから全身倦㤐, 瘦 せ, 下痢, 便秘, 足趾の難治性潰瘍, 歩行困難.

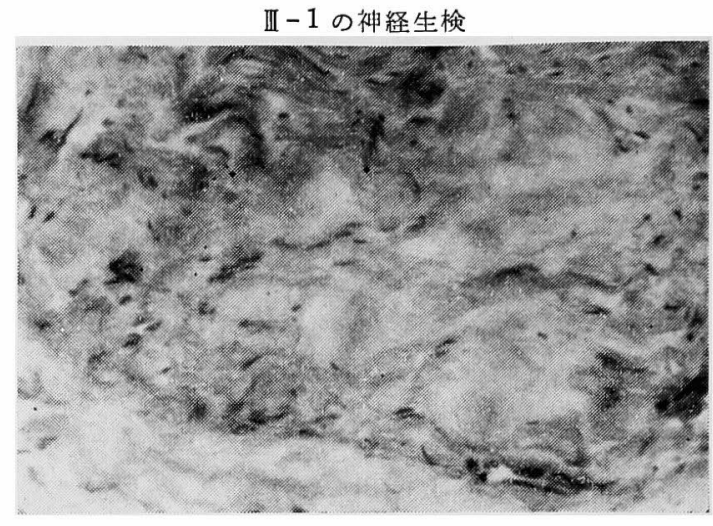

III-2 の神経生検

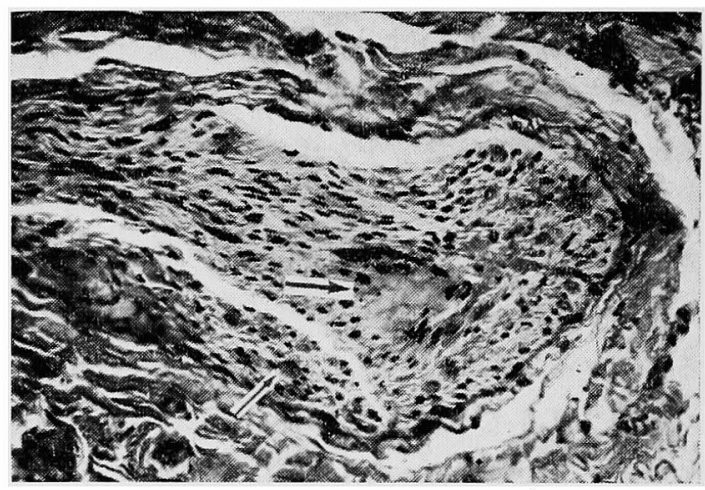

症例 2（II-2) のN. Suralis の生検所見. Perineuriumは肥厚し, 神経線維（細い矢印）は減少 して，特に細い神経線維はほとんど認められず， Endoneuriol fibrosisが強い。注活中央にアミロ イドの沈着がみられる (太い矢印) (Masson trichrome染色 $\times 200$ ).

写真 1。神経生検像

症例 4 と注とんど同じ症状とのことで，34才の時 病気を苦に自殺.この例も同じく癩と診断されて いた。

\section{考案 \\ I. 症例についての考察}

症例 1，2：臨床所見で目立つことはその特 異な知覚障害, 運動障害および発汗, 唾液と涙の 減少, 起立性低血圧, 瞳孔異常, インポテンッ, 下痢, 便秘等の多彩な自律神経症状である. 知覚 障害は四肢では対称的，遠位性の知覚低下（いわ ゆるglove and stocking type) が見られ，躯幹で は腹側，ことにその正中部に近づくほど知覚障害 
が著明である。すなわら末梢神経の走行において 春䯣から遠ざかる汪ど障害が著明で，障害域心境 界が不鮮明ですることと合わせて，末梢神経の障 害を意味する。ささらに興味深いことは，温痛覚， 触覚, 深部覚の間に著しい解離が見られることで ある。また運動神経の障害は知覚障害に比べて軽 微である。

これらの臨床所見はすべて「ことに小経線維の 脱落が著しかつた」という末梢神経の生検所見に 合致している，ア症の神経障害がはたしてアミロ イド沈着の機珹的圧迫によるものか，それとも栄 養血管にamyloid か，古るいは何らかの不明な中毒性・代謝性障害 によるものか，楛説あつてまだ明らかでない，

起立性低血王症がア症に伴つて見られる事は古 くから知られているが，その頻度はさ㭱ど高いも のではない，Kyle5)らは 138例の原ア症患者中， 11例 ( $8 \%$ ) k起立性低血圧があつたと報告してい る。起立性低血圧症の病態生理にかんしては, Wagner ${ }^{6}$ の詳細な研究があるが，まだ十分に明ら かでないおをらくamyloid沈着による自律神経 障害が主体をなし，これに心筋，血管の障害，さ らに副腎の㙨能不全等が加わつて発現するもので あるう。なお（II-2）例ではFlovinaf (Squib) を用いて，起立性低血圧，失神発作にきわめて有 効であつた。涙, 唾液分泌低下の著しい原了症の

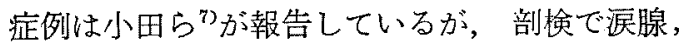
唾液腺に著明なアミロイド沈着を認めたと記载し て和り，本例に和いても自律神経障害の汪かに腺 局所のアミロイド沈着が原因となつている可能性 も否定できない，しかし，発汗異常の方は知覚障 害とほ心゙同じ分布域を示し，皮膚生桱でも汗腺そ のるのの障害を特に認めていないので，自律神経 障害によるるのと考えてよかるう。またAdamsStokes 発作にしても心筋自体の障害に加光て，心 外性の因子，すなわち自律神経の調節障害が大き な原因となつていたに相違ない，下痢，便秘その 他の腹部症状は原ア症によく見られる症状で，な かんずく家族性原ア症によくみられる。 その原因については，1）amyloidが自律神経 に沈着し腸管の蠕動，分泌が障害される，2）腸 管壁へのamyloid沈着が壁內の神経盖を刺激す る．3）腸管壁へのamyloid沈着が腸管の運動・ 吸収を妨げる．4）amyloid 沈着による脺機能不 全で脂肪下痢を来たすなどがあげられている。

インポテンツもまた主として白律神経障害によ るものであるらが，amyloid沈着による翌丸組織 自体の障害も原因となつているかるしれない，事 実いくつかの剖検で等丸にamyloidの沈着が確認 されている。な挌Kaufmannら ${ }^{8)}$ による家族性 原了齐にはamyloid沈着による硝子体混浊がしば しばみられるといら．弟例にはをのよらな所見が あり，本邦では最初と思的れる。 巨大舌が家旅性 原ア症にみられるという報告はなく（保かにRukavina ${ }^{9)}$ の報告に疑わしい1例がある)この点例外 というべきであるら。なお兄例では入院前後に黄 应が㕛られた。これは肝炎の合併も否定できない が， amyloid肝によつても説明されるであるう。

症例 3，4，5：いずれもすでに死亡して必 り，当時の病状の正確な記載も得られないため断 定はできないが，家族から聴取した病歴で沈症 状, 発病年令, 経過等いずれも家族性原了症を推 定させるに十分である. 遺伝形式としては常染色 体優性が考えられ，従来の報告と一致している。

\section{II. 家族性原発性amyloidosisについての臨床 統計的考察}

原ア症の中に，1）家族性の発現を示し，2） 知覚障害その他の神経症状が前景に立ち，3）多 くは20代，30代といら若い時期に発症し，4）長 い経過をとる，1群のあることはかなり確実とい 党よう。欧米ではAndrade ${ }^{103} の$ 報告をはじめとし $\tau$, Rukavina $5^{9)}$, Schlesinger $5^{11)}$, Kaufmann $ら^{8)}$ ，Delank $5^{12)}$ の報告があり，現在すでに 130 例を越克る症例が見出导れている。しかし本邦 に打ける報告はをだきわめて少ない，家族性原つ 症を非家族性原了症と比較するとき，両者の間比 かなり大きな差異があることはしばしば指摘され てきた。しかしそれはいわば漠然とした印象とし 
て述べられているだけで，はたしてどの程度の差 があるか，両者を区別することに何か本質的な意 味があるのかなどという点についてははとんど触 れられていない，そこでまずわれわれは文献例 をも上に両者を比較してみた，家族性原了症の症 例としては，前記欧米の報告例にKantarjianら

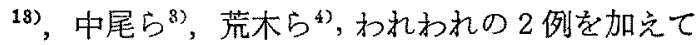
63例を選び，非家族性原ア症としては本邦例の中 から比較的記載の詳細な56例を選んだ。発病年令 のピークは家族性では30代，非家族性の群では50 代であるが，10〜70代に分布している．発病後の 経過は家族性原ア症で長いことが特徵的である。 また死亡者が非常に少ないことが注目される。

初発症状について耐者を比較してみると，家族 性では知賞異常，知賞低下等で始まるのか汪倒的 に多いのに対し，非家族性では浮腫，全身倦意，腹 部症状て始まるものが多い．また臨床定状全体を とつてみても，両者に明らかな差がある（表 2 ）。 症例の記載は各報告により区今で，この数值が そのまま症状発現の頻度を正しく表わしていると は考光ないが，その臨床像の大まかな傾向を示し ているとい兄よう。非家族性の症状が浮腫，肝尰

表2。家族性抢よび非家族性原了症に打ける初発 症状括よび症状の比較

\begin{tabular}{|c|c|c|c|c|}
\hline \multicolumn{2}{|l|}{ 等禁性等筑性了症 } & \multicolumn{3}{|c|}{ 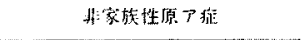 } \\
\hline 知觉佳下 & $83(\%)$ & 浮脽 & $(26 \%)$ & $73(0)$ \\
\hline 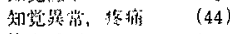 & 74 & 架自属 & & 73 \\
\hline 筙力组下 & 59 & 耗大 & & 63 \\
\hline 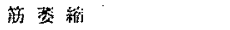 & 50 & 心啲太 & & 51 \\
\hline 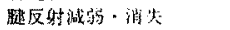 & 46 & 笻 桖 & & 49 \\
\hline 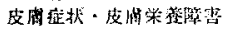 & 33 & 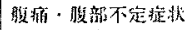 & $k(21)$ & 43 \\
\hline 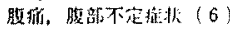 & 31 & 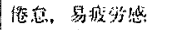 & $(24)$ & 39 \\
\hline 㑊秘 (21) & 31 & 腹 水 & & 35 \\
\hline 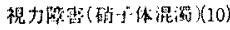 & 28 & 和知不擗 & (9) & 33 \\
\hline 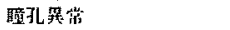 & 28 & 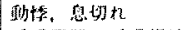 & (17) & 33 \\
\hline 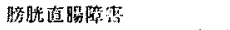 & 26 & 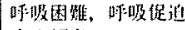 & & 29 \\
\hline 体算減少 & 26 & 出血野台 & (9) & 27 \\
\hline 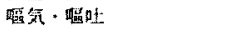 & 24 & $\mathrm{~F}$ 科 & & 24 \\
\hline 下梸 & 24 & 心椎㔽 & & 24 \\
\hline 霍 推 & 20 & 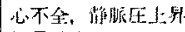 & & 20 \\
\hline$\therefore$ 腭大 & 19 & 退骨娍当 & & 20 \\
\hline 心雑意 & 17 & 呧组压 & & 20 \\
\hline 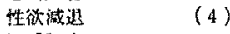 & 17 & E大思 & & 18 \\
\hline 肝堙大 & 15 & 㗀 水 & & 16 \\
\hline 塤球㛪出 & 15 & 体场減少 & & 14 \\
\hline 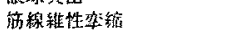 & 13 & 的 血 & & 14 \\
\hline 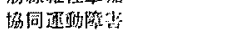 & 13 & 彭 椬 & & 14 \\
\hline 算折 - 骨変化 & 13 & 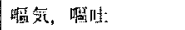 & & 14 \\
\hline 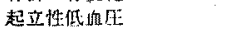 & 11 & 佂秘 & & 12 \\
\hline 兵微不报 & 11 & 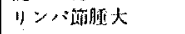 & & 12 \\
\hline
\end{tabular}

大, 心肥大, 貧血, 腹痛等と全身蔵器への広範な 沈着をそのまま示すかのように多彩であるのに比 し，家族性の症状はその大半が神経症状，自律神 経症状で占められている。

さて家族性原了症と非家族性原ア症との統計的 な比較は上述のように差があるが，個々の症例で はその違いは必ずしも明らかでない。

非家旅性原ア症の中でも，たとえばMunsatら 14)の症例，冲中ら ${ }^{15)}$ の症例等は症状，経過の点 で，家族性原ア症と汪とんど区別しにくい。むし 家族発生を認めないといら違いだけならば，Andradeの 報告例中に含まれる13例 のsporadic case とはいかなる差があるというべきであろうか。ま た問題は家旅性原了症とよばれる症例にもいくつ かある。たとえばAndrade ${ }^{10}$ の例，Rukavinaら ${ }^{9^{2}}$ の例，Schlesingerら ${ }^{111}$ の例をそれぞれ仔細に検討 すると少なからぬ差がある。これらが同一疾患と いう確証はない，家旋性原ア症の中にはまた神経 症状の目立たないあるいは全く神経症状を示さ ない症例わ斿ずかながら報告されている。たとえ ばFredriksenら ${ }^{16)}$ の例は心不全が拈むな症状で， 神経症状としては一部の者に一過性の異常感覚を 認めたに過ぎない，Ostertag ${ }^{199} の$ 例は腎障害が主 で神経症状は全くない，いわゆるAndrade型の家 族性原ア症とこれらの症例との異同についてはわ かっていない，また恐らく别個の疾患単位と考完

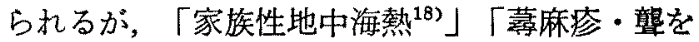
伴う amyloidosis ${ }^{199} 」$ 等も「家族性アミロイドーシ ス」といら点では共通である．最終的には同し

\section{表 3. Amyloidosisの分類}

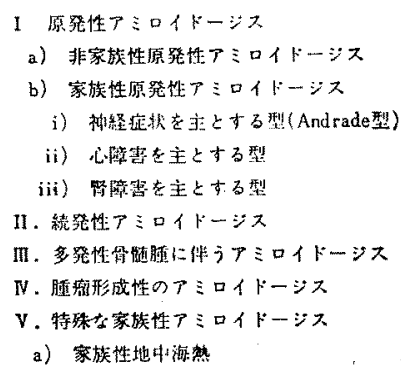

a) 家族性地中㵊整

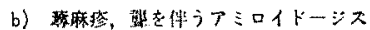


amyloid沈着といら表現をとるにしても，その原 因しなる代謝経路の蹱害を異にするものなのであ ろらか.最後にamyloidosisの一応の分類を行なつ てみたが（表-3），上述の疑問が残されている以 上これも便宜的なものである。

\section{結論}

1）一家系13人中 5 人に発病をみた家埃性原発 性amyloidosisについて報告した。症例 1 は未梢 神経型の知覚障害, 筋力低下に加觉て, 起立性低 血王，発汗，唾，淚の減少乞の他の自律神経症状 を呈し，経過中一時黄渲を呈した。

末梢神経の生検でアミロイドの沈着を証明し た. 症例 2 る末梢神経型の知覚障害，筋力低下な と症例1 と似ているが;, Adams-Stokes発作があり， 末梢神経，直腸等の生検でamyloidの沈着を証明 した．症例 3，4，5はすで死亡しているが， 生前の病歷からamyloidosisであることが推定さ れた。遗伝形式は常染色体儤性が考えられた。

2）文献例，自虽例を电と，家族性原発性 amyloidosisの臨床統計的考察を行なつた。

\section{文献}

1）中川定明：我国に於ける amyloidosis の 税尌的 研究，日内会誌，54（3）：267，1965，-2）太田 邦夫 : 所㯰類筑粉症 (会) 日本病理学会々誌, 33: 236 , 昭19. 一3) 中尾壱久, 東籍英夫, 古川哲夫,

豊會康夫 : Familial Amyloid Neuropathy 01 家 系，臨床神経学（会）6:369, 1966，一4）荒术淑 郎, 馬渡志郎, 太四典也，岩下宏，黑岩義五郎：末 梢性ニニーロパチーを主徽とした家族性原発性了 ミロイドージス,一家柔10例の自験例を中心とした 文献的考察，脳之神経（投稿中），一5）Robert A. Kyle, Bruce A. Kottke, Alexander Schirger.: Orthostatic hypotension as a clue to primary systemic Amyloidosis, Ciculation $34: 883,1966$. -6) Henry N. Wagner. Jr.: Orthostatic Hypote- nsion, Bull, Johns Hopkins Hosp. 105 : 322 , 1959，－7）小田正幸，村田順他：原発性類知粉症 の 1 剖袷例, 日本臨床, $24(2): 330,1966$. -8) Herbert E. Kaufmann, Louis B. Thomas.: Vitreous opacities diagnostic of Familial Primary Amyloidosis, New Engl. J. Med. 261 : 1267, 1959. -9) John G. Rukavina, Walter D. Block, Charles E. Jackson et al.: Primary Systemic Amyloidosis.: A review and an experimental, genetic, and clinical study of 29 cases with particular emphasis on the familiar form. Medicine $35: 239$, 1956. - 10) Corino Andrade.: A peculiar form of peripheral neuropathy, Brain $75: 408,1952$. -11) Adolph S. Schlesinger, Virginia A. Duggins, Elmo F Masucci.: Peripheral neuropathy in familiar primary amyloidosis.: Brain $85: 357$, 1962. - 12) Heinz-Walter Delank, Gerhard Koch, Günther Könn, et al.: Familiäre Amyloid-Polyneuropathie Typus Wohlwill-Corino Andrade, Ärtliche Forsch. 19 (8): 401, 1965. -13) Artin D. Kantarjian, Russel N. De Jong.: Familial Primary Amyloidosis with nervous system Involvement, Neurology. $3: 399,1953$. -14) Theodore L. Munsat, Alvin F. Poussaint: Clinical manifestations and diagnosis of amyloid polyneuropathy. Neurology $12: 413,1962,-15)$ 田扨 集, 福地創太郎, 葛谷健, 井林博, 冲中重雄: 生前 に猃断し得大原発性amyloidosisの 1 剖検例 (会) 日内会誌，48(2)：321, 昭34. - 16) Thorkild Frederiksen, Henning G $\phi$ tssche et al.: Familiar Primary Amyloidosis with severe Amyloid Heart Disease. Amer. J. of Medicine. 33 : 328, 1962. -17) B. Ostertag.: Familiäre Amyloid-Erkrankung. Z.menschl, vererb Konstit. lehre. $30: 105$, 1950. -18) H.Heller, E.Sohar, M. Pras.: Ethnie Distribution and Amyloidosis in Familial Mediterranean Fever.: Path. Microbiol. 24 : 718, 1961. -19) Thomas J. Muckle, Michael Wells.: Urticaria, deafness, and amyloidosis.: A new heredofamilial syndrome.: Quart. J. med. 31 : $235,1962$. 